\title{
DELINEASI LANDAS KONTINEN EKSTENSI DI LUAR 200 MIL LAUT MELALUI PENARIKAN GARIS HEDBERG DARI KAKI LERENG INVESTIGATOR RIDGE
}

\author{
Khomsin $^{1)}$, Muammar Khadafi Ashar ${ }^{1)}$, Arif Rahman ${ }^{2)}$ \\ 1) Jurusan Teknik Geomatika, FTSP, ITS, \\ ${ }^{2)}$ Pusat Pemetaan Batas Wilayah Badan Informasi Geospasial, Cibinong \\ Email: khomsin95@yahoo.com
}

\begin{abstract}
Abstrak. Indonesia, sebagai negara kepulauan (archipelagic state) menurut UNCLOS 1982 berhak untuk mengklaim wilayah maritim tertentu yang ditarik dari garis pangkal yang telah ditetapkannya. Seperti yang telah dijelaskan pada pasal 76 UNCLOS 1982, negara pantai berhak untuk melakukan pengajuan submisi untuk mengklaim batas terluar landas kontinen melebihi 200 mil laut atau yang biasa disebut dengan Landas Kontinen Ekstensi (LKE). Pengajuan klaim LKE harus berlandaskan pada metode yang telah diatur oleh CLCS (Commission on the Limits of the Continental Shelf). Untuk itu diperlukan sebuah test/uji untuk menentukan apakah sebuah negara berhak untuk mengajukan klaim Landas Kontinen Ekstensi melebihi 200 mil laut. Pada kasus ini, data yang digunakan untuk mengajukan LKE adalah data bathimetri global yang diperoleh dari Global (GEBCO) dengan akurasi 30 detik. Sedangkan data ketebalan sedimen yang digunakan adalah data sedimen global yang tersedia dalam software CARIS. Pada penelitian ini, lokasi yang diusulkan untuk studi kasus pengajuan LKE adalah sebelah Barat Daya Pulau Sumatera. Metode yang digunakan untuk penarikan batas LKE adalah metode Hedberg yang ditarik melalui kaki lereng Investigator Ridge. Hasil dari test yang dilakukan di wilayah ini membuktikan bahwa Indonesia dalam hal ini lokasi sebelah Barat Daya Pulau Sumatera berhak untuk mengajukan Landas Kontinen Ekstensi lebih dari 200 mil laut.
\end{abstract}

Kata Kunci: Unclos 1982; Hedberg; Investigator Ridge; Landas Kontinen Ekstensi

\begin{abstract}
Indonesia, an archipelagic state which is according to UNCLOS1982, is entitled to claim certain maritime areas from the baseline that has been set forth. Based on UNCLOS 1982 at article 76, coastal states have the right to do the filing of submissions to claim the outer limit of the continental shelf exceeding 200 nautical miles or commonly called the Extended Continental Shelf (ECS). ECS claim must be based on methods that have been set by the CLCS (Commission on the Limits of the Continental Shelf). It needs a test to determine whether a state has the right to claim the extension of the continental shelf exceeding 200 nautical miles. In this case, the data used to apply ECS are a global bathymetric data which obtained from (GEBCO) with 30 seconds accuarcy. The other data used is the thickness of sediment globally available in the CARIS software. In this study, the proposed location for the submission is southwest of Sumatra Island, Indonesia. The method used for the withdrawal limit is the Hedberg method and is drawn through foot of slope plus $60 \mathrm{nmfrom}$ Investigator Ridge. The Results of this study is Indonesia is eligible to apply for the Extended Continental Shelfmore than 200 nautical miles in southwest of Sumatra Island.
\end{abstract}

Keywords: UNCLOS 1982; Hedberg; Investigator ridge;Extended Continental Shelf

\section{PENDAHULUAN}

Indonesia merupakan salah satu negara kepulauan terbesar di dunia. Indonesia telah meratifikasi hukum laut internasional United Nations Conventions On The Law of The Sea (UNCLOS) 1982 dengan Undang-undang Nomor 17 Tahun 1985. Sebagai negara kepulauan, Indonesia berhak untuk mengajukan penambahan batas wilayah terluarnya. Menurut UNCLOS Pasal 76, negara pantai mempunyai kesempatan untuk melakukan submisi batas terluar landas kontinen lebih dari 200 mil laut.

Salah satu kawasan maritim Indonesia yang berpotensi untuk diajukan klaim penambahan 
Landas Kontinen Ekstensi adalah kawasan maritim di sebelah Barat Daya Pulau Sumatera (Alina, 2013). Hal ini disebabkan adanya Investigator Ridge di kawasan tersebut. Penegasan landas kontinen di kawasan ini merupakan sesuatu yang penting mengingat potensi sumber daya alam yang terdapat di dalamnya.

Penentuan Landas Kontinen Ekstensi memerlukan data dan informasi yang digunakan untuk membuat garis batas terluar. Berdasarkan UNCLOS 1982 Pasal 76 Ayat 4, data yang digunakan untuk penarikan garis batas terluar adalah data bathimetri dan data sedimen. Data bathimetri digunakan untuk menentukan Foot Of Slope (FOS) (kaki lereng) kontinen. Petunjuk teknis dan ilmiah penentuan batas terluar Landas Kontinen Ekstensi ini ditetapkan secara resmi oleh Commission on the Limits of the Continental Shelf (CLCS) (United Nations, 2005). Selain itu, prosedur penentuan Landas Kontinen Ekstensi ini juga dijabarkan dalam Manual on the Technical Aspects of the United Nations Convention on the Law of the Sea (TALOS) (IHO, IAG, ABLOS, 2006). Kedua aturan tersebut digunakan untuk menentukan ada atau tidak adanya Investigator Ridge untuk mengajukan klaim landas kontinen di luar 200 mil laut pada kawasan maritim sebelah Barat Daya Pulau Sumatera.

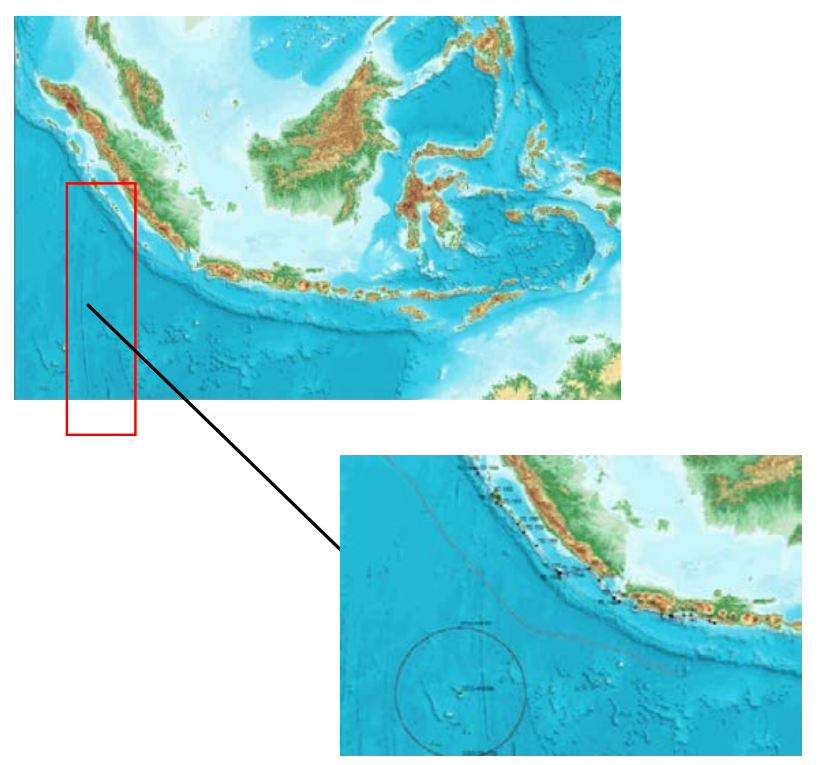

Gambar 1. Kawasan Maritim Sebelah Barat Daya Pulau Sumatera (BIG, 2014)

\section{METODOLOGI}

\section{Lokasi Penelitian}

Lokasi penelitian ini berada di kawasan maritim sebelah Barat Daya perairan Pulau Sumatera, tepatnya di kawasan Samudera Hindia. Kawasan maritim ini berada pada koordinat:

$$
15^{\circ} 17^{\prime} 46^{\prime \prime} \mathrm{LS}-90^{\circ} 8^{\prime} 12^{\prime \prime} \mathrm{BT} \text {, dan }
$$$$
1^{\circ} 14^{\prime} 27^{\prime \prime} \mathrm{LU}-15^{\circ} 7^{\prime} 16^{\prime \prime} \mathrm{BT} \text {. }
$$

\section{Kerangka Hukum}

Penarikan landas kontinen di luar 200 mil laut diatur dalam BAB VI UNCLOS pasal 76 . Berikut adalah bunyi UNCLOS yang dimaksud:

Pasal 4:

Negara pantai berhak menetapkan pinggiran luar tepian kontinen lebih dari $\mathbf{2 0 0}$ mil laut dari garis pangkal.

Pasal 5:

Batas maksimum tepian luar kontinen tidak boleh lebih dari 350 mil laut atau 100 mil laut dari garis batas kedalaman $2500 \mathrm{~m}$.

Pasal 7:

Metode yang digunakan untuk menetapkan tepian terluar kontinen yaitu dengan menarik garis-garis lurus yang tidak melebihi 60 mil laut panjangnya, dengan menghubungkan titik-titik tetap, yang ditetapkan dengan koordinatkoordinat lintang dan bujur.

\section{Investigator Ridge}

Penarikan Landas Kontinen Ekstensi di luar 200 mil laut umumnya ditarik dari garis pangkal (baseline) yang menghubungkan titik-titik dasar (basepoints). Dalam penelitian ini, metode penarikan batas landas kontinen di luar 200 mil laut dilakukan dengan memanfaatkan keadaan fitur dasar laut yang berupa sebuah punggung laut (ridge) yang disebut dengan Investigator Ridge.

Landasan dari penarikan Landas Kontinen Ekstensi melalui punggung laut juga diatur dalam UNCLOS pasal 76 ayat 6 yaitu : Walaupun ada ketentuan ayat 5, pada bukti-bukti dasar laut, batas luar landas kontinen tidak boleh melebihi 350 mil laut dari garis pangkal dari mana laut teritorial 
diukur. Ayat ini tidak berlaku bagi elevasi dasar laut yang merupakan bagian-bagian alamiah tepian kontinen, seperti pelataran (pateau), tanjakan (rise), puncak (caps), ketinggian yang datar (banks) dan puncak gunung yang bulat (spurs) nya. Penarikan Landas Kontinen Ekstensi berdasarkan Investigator Ridge pernah diterapkan oleh Selandia Baru dan telah disetujui oleh CLCS.

\section{Metode Penarikan LKE}

Secara umum metode penarikan LKE Kawasan Maritim Sebelah Barat Daya Sumatera adalah sebagai berikut:

1. Penentuan basepoint (titik pangkal) di sepanjang titik terluar wilayah Sumatera bagian barat;

2. Penarikan garis pangkal lurus (straight baseline) dari titik-titik pangkal yang sudah diplot;

3. Penggambaran kontur bathimetri dengan data global yang diperoleh dari GEBCO;

4. Penentuan ketebalan sedimen dari data sedimen yang ada di CARIS (CARIS, 2012);

5. Penentuan Investigator Ridge dari kontur bathimetri yang sudah terbentuk;

6. Penentuan foot of slope dari Investigator Ridge;

7. Menarik batas Landas Kontinen Ekstensi dengan metode Herdberg.

\section{HASIL DAN PEMBAHASAN}

\section{Bagian Plotting Titik Dasar dan Garis Pangkal}

Titik dasar dan garis pangkal merupakan bagian penting dalam penarikan batas maritim. Semua batas maritim pada awalnya ditarik melalui garis pangkal yang menghubungkan titik-titik dasar. Pada daerah penelitian, ada 31 titik dasar yang digunakan, yaitu titik-titik dasar:

TD.171C, TD.171, TD.170, TD.168, TD.167,

TD.164，TD.164B, TD.162, TD 161B, TD.161,

TD.159, TD.158, TD.156, TD.155, TD.154B,

TD.154，TD.154A, TD.152，TD.151，TD.148,

TD.148A, TD.147, TD.146, TD.145, TD.144,

TD.144C，TD.144A, TD.143，TD.142，TD.141，

TD.140.
Data koordinat titik-titik dasar tersebut didapatkan dari BIG. Plotting titik dasar dan penarikan garis pangkal bisa dilihat seperti pada Gambar 2.

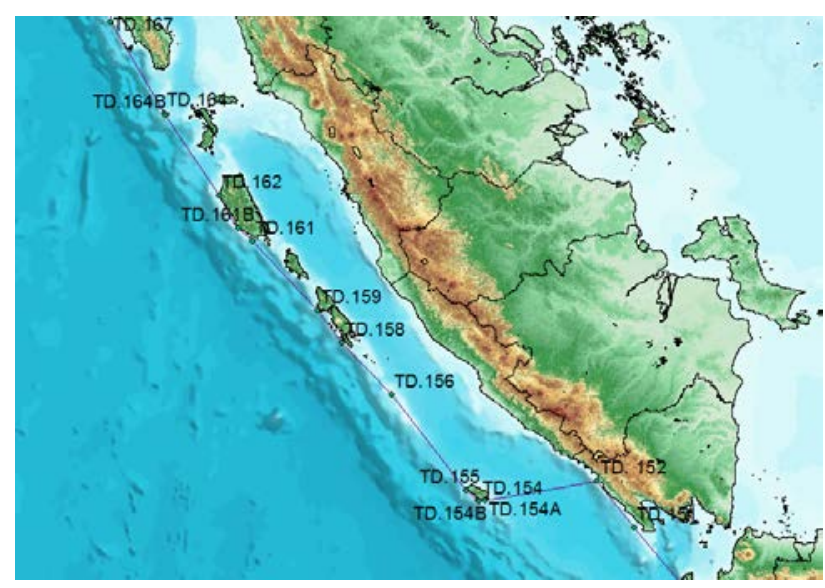

Gambar 2. Plotting TD dan Baseline

\section{Test of Appurtenance}

Test of Appurtenance dilakukan untuk menentukan sah atau tidaknya sebuah negara pantai untuk melakukan delineasi batas terluar landas kontinen di luar 200 mil laut melalui perpanjangan alamiah dari wilayah kontinennya. Test of Appurtenance secara garis besar dapat dibagi menjadi 2 tahap, yaitu :

1. Tes Radius 200 mil laut;

2. Foot of Slope Test.

\section{Tes Radius $\mathbf{2 0 0}$ mil laut}

Syarat negara pantai untuk mengajukan batas Landas Kontinen Ekstensi lebih dari 200 mil laut jika panjang luasan landas kontinen atau perpanjangan alamiah dari suatu negara melebihi 200 mil laut. Tes radius 200 mil laut bertujuan untuk melihat apakah kawasan maritim sebelah barat daya Pulau Sumatera melebihi 200 mil laut atau tidak yaitu dengan menggunakan metode buffer. Pada Gambar 3 bisa dilihat bahwa perpanjangan alamiah dari kontinen, yaitu Investigator Ridge memiliki panjang melebihi 200 mil laut. 


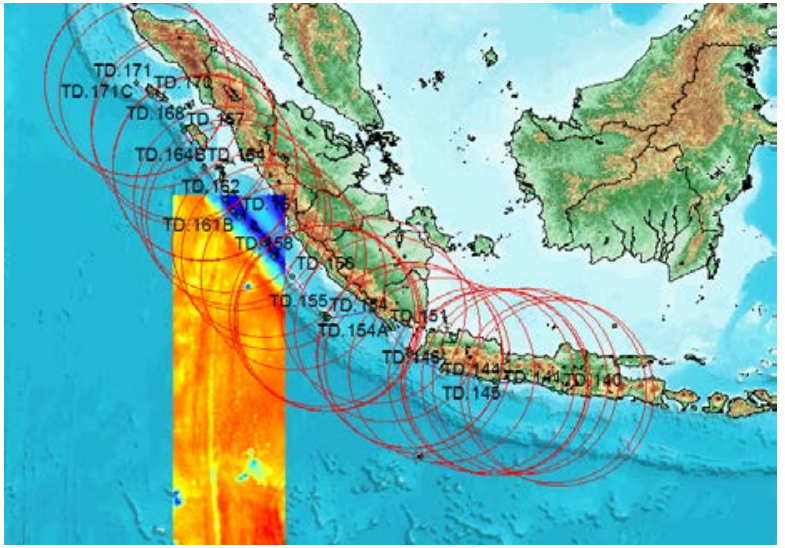

Gambar 3. Tes Radius 200 Mil Laut

\section{Tes Foot of Slope (FOS)}

Menurut UNCLOS Pasal 76 ayat 4 (b), foot of slope (kaki lereng) didefinisikan sebagai titik perubahan maksimum dalam perubahan gradien dari bentukan fitur di dasar laut. Titik FOS digunakan sebagai acuan untuk membuat garis formula, yaitu garis Gardiner dan Hedberg. Dalam penentuan titik FOS ini menggunakan data bathimetri global dari GEBCO dengan ketelitian 30 detik. Setelah didapatkan raster wilayah penelitian, maka kemudian yang dilakukan ialah membuat FOS Marker di wilayah penelitian, dengan cara menarik garis profil kedalaman dari arah dalam area kontinen ke arah luar, dalam kasus ini ialah ke arah Barat dan Timur dari masing-masing sisi Investigator Ridge. Gambar 4 menunjukkan FOS di area studi.

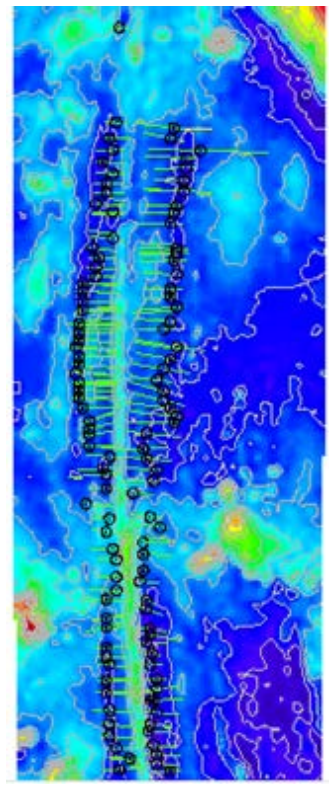

Gambar 4. FOS di Area Studi

Gambar 5 menunjukkan bahwa garis profil kedalaman merupakan kaki lereng dari kontinen, karena terjadi perubahan gradien dari puncak ke kaki lereng (foot of slope) Investigator Ridge. Pada foot of slope test ini bisa dipastikan bahwa garis terluar Landas Kontinen Ekstensi bisa ditarik melalui kaki lereng Investigator Ridge.

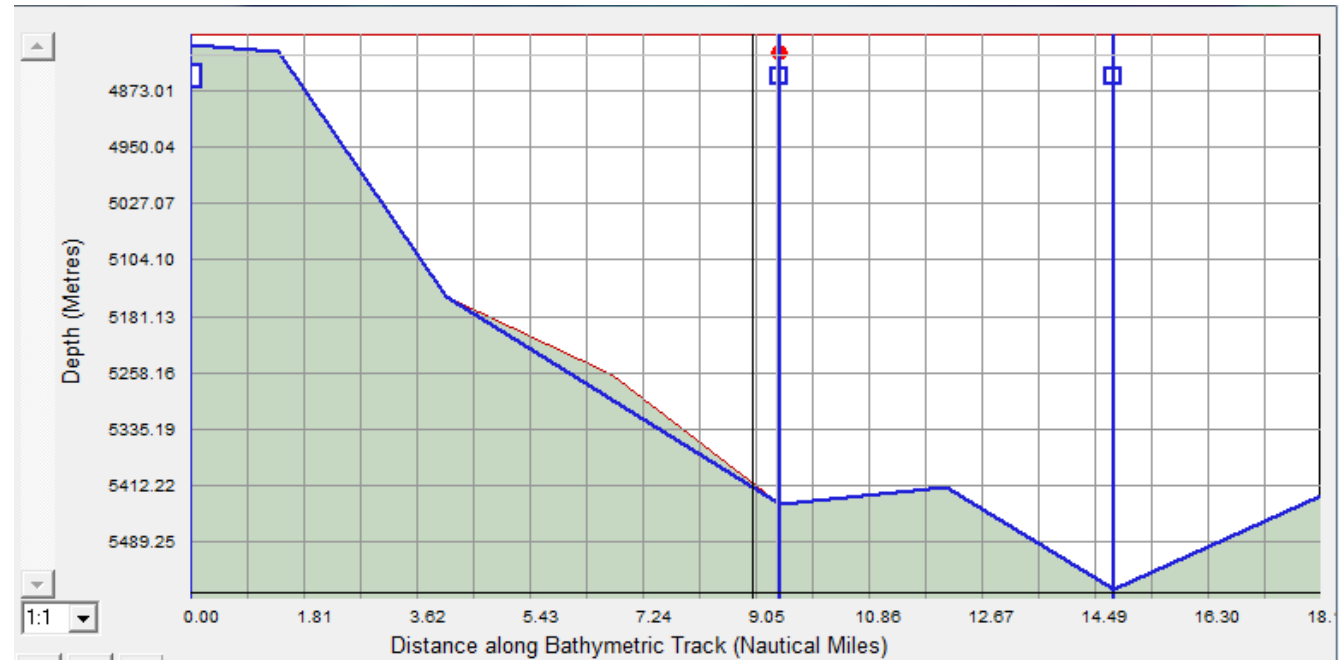

Gambar 5. Profil FOS di Area Studi 


\section{Penarikan Garis Hedberg (FOS + 60 Mil Laut)}

Garis Hedberg (Hedberg Line) merupakan salah satu dari 2 syarat yang membolehkan suatu negara untuk mengklaim LKE. Garis ini ditarik dari kumpulan titik FOS yang sebelumnya telah dibuat, kemudian ditarik ke arah luar titik FOS sejauh 60 mil laut (Indrayanti, 2014). Pada kasus ini Garis Hedberg ditarik dari titik FOS dari kaki lereng Investigator Ridge ke arah Barat dan ke arah Timur sejauh 60 mil laut. Hasil penarikan garis Hedberg dapat dilihat pada Gambar 6 .

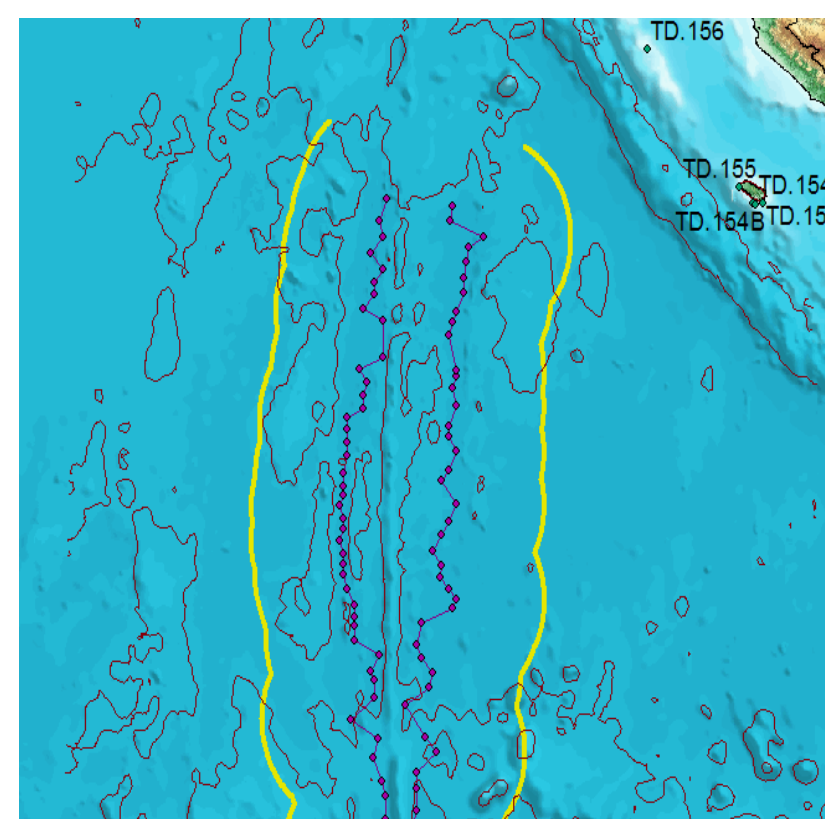

Gambar 6. Hasil Penarikan Garis Hedberg (warna kuning)

\section{Penentuan Garis Terluar Landas Kontinen Ekstensi}

Batas terluar dari Landas Kontinen Ekstensi melebihi 200 mil laut tidak boleh lebih dari 350 mil laut atau 100 mil laut dari kedalaman 2500 m (Khafid, 2011). Pemilihan syarat tersebut dipilih yang paling menguntungkan untuk negara yang bersangkutan. Pada kasus ini syarat yang paling menguntungkan adalah batas terluar sejauh 350 mil laut dan penggunaan garis Hedberg (FOS +60 mil laut). Hasil kombinasi dari dua garis ini bisa dilihat seperti pada Gambar 7.

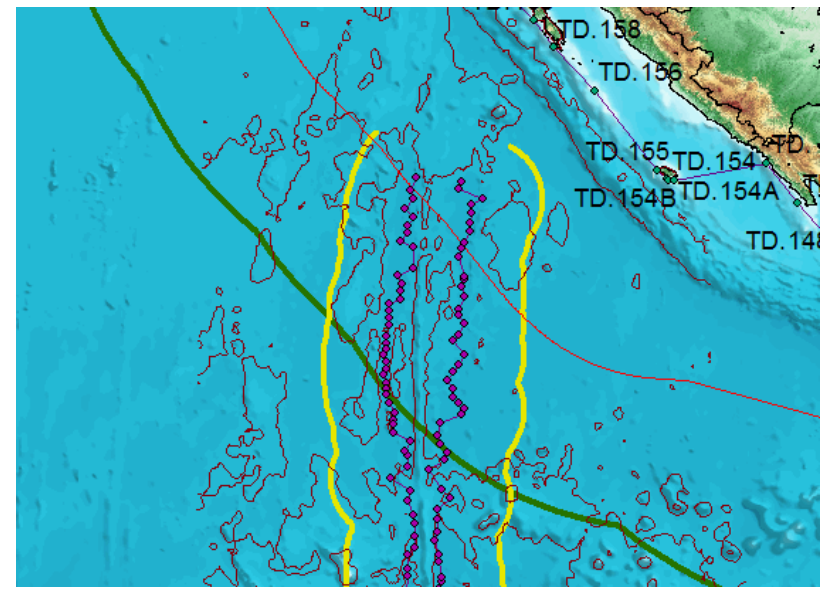

Gambar 7. Batas LKE (warna hijau tua) Hasil Studi

\section{PENUTUP}

Simpulan

Berdasarkan UNCLOS 1982 Pasal 76 dan dengan menggunakan data bathimetri global dari GEBCO serta data sediment global dari CARIS, Indonesia berhak untuk mengajukan Landas Kontinen Ekstensi (LKE) sejauh 350 mil laut untuk kawasan maritim Barat Daya Pulau Sumatera. Indikasinya, di kawasan tersebut terdapat Investigator Ridge yang dapat digunakan sebagai acuan untuk menarik batas terluar LKE dari FOS + 60 mil laut dari kaki Investigator Ridge.

\section{Saran}

Hasil penelitian ini dapat digunakan oleh Pemerintah Indonesia khususnya BIG sebagai acuan awal untuk mengajukan LKE di luar 200 mil laut. Selanjutnya perlu dilakukan penelitian lebih lanjut dengan pengukuran yang lebih detil untuk mendapatkan data yang lebih akurat.

\section{Ucapan Terima Kasih}

Penulis mengucapkan terima kasih kepada Badan Informasi Geospasial khususnya Pusat Pemetaan Batas Wilayah yang telah membantu dalam hal penyediaan data, software dan peralatan yang digunakan untuk penelitian ini. 


\section{DAFTAR PUSTAKA}

Alina, Aldea Noor, 2013. Kajian Landas Kontinen Ekstensi Batas Maritim Perairan Barat Laut Sumatra. Surabaya: Institut Teknologi Sepuluh Nopember.

CARIS, 2012. CARIS LOTS User Guide. Fredericton: CARIS.

IHO, IAG, ABLOS, 2006. A Manual on Technical Asect of The United Nations Convention on The Law of the Sea. Monaco: Internationa Hydrographic Bureau.

Indrayanti, Meylia Ayu, 2014. Kajian Penentuan Landas Kontinen Ekstensi Di Kawasan Maritim Sebelah Selatan Nusa Tenggara. Surabaya: Institut Teknologi Sepuluh Nopember.

Khafid, 2011. Pengalaman Melakukan Parsial Submisi Landas Kontinen Indonesia di Luar 200 Mil Laut di Sebelah Barat Laut Sumatera untuk Mendukung Penyusunan Rancangan Undang-Undang Landas Kontinen Indonesia. Bogor: Badan Koordinasi Survei dan Pemetaan Nasional.

UNCLOS, 1982. United Nation Convention on the Law of the Sea. Använd den 5 Oktober 2014. http://www.un.org/depts/los/convention_agreemen ts/texts/theLOSC/unclos_e.pdf.

United Nations, 2005. Training Manual for Delineation the Outer Limits of the Continental Shelf beyond 200 Nautical Miles and for Preparation of Submission to the Commisions on the Limits of the Continental Shelf. New York: United Nations Publication. 